\title{
Application of Geophysical Methods to Building Foundation Studies
}

\author{
Folahan Peter Ibitoye ${ }^{1,2}$, Felix Vincent Ipinmoroti ${ }^{2}$, Mudasiru Salami ${ }^{2}$, Kunle Joseph Akinluwade ${ }^{2,3 *}$, \\ Adeyinka Taofeek Taiwo ${ }^{2}$, Adelana Rasaki Adetunji $\mathbf{i}^{2,4}$ \\ ${ }^{1}$ Department of Applied Geophysics, Federal University of Technology, Akure, Nigeria \\ ${ }^{2}$ Prototype Engineering Development Institute, National Agency for Science and \\ Engineering Infrastructure (NASENI), Ilesa, Nigeria \\ ${ }^{3}$ Department of Materials Science and Engineering, African University of Science and Technology (AUST), Abuja, Nigeria \\ ${ }^{4}$ Department of Materials Science and Engineering, Obafemi Awolowo University, Ile-Ife, Nigeria \\ Email: jakinluwade@yahoo.com, folaibitoye@yahoo.com
}

Received August 16, 2013; revised September 19, 2013; accepted October 21, 2013

Copyright (C) 2013 Folahan Peter Ibitoye et al. This is an open access article distributed under the Creative Commons Attribution License, which permits unrestricted use, distribution, and reproduction in any medium, provided the original work is properly cited.

\begin{abstract}
A geophysical survey involving the electrical resistivity method utilizing the Vertical Electrical Sounding (VES) and Electrical Imaging Techniques was conducted around the premises of an area within south-western Nigeria with the aim of studying structural defects which may be responsible for future problems and characterizing the soil conditions of the site. A total of 15 VES stations were occupied using Schlumberger Configuration with AB/2 varying from 1 to $65 \mathrm{~m}$. In the electrical imaging, dipole-dipole array was adopted and the two traverses were occupied in the S-N and E-W directions close to where wall cracks and subsurface problems were manifested. Five main geoelectric sequences were delineated within the study area; these include the topsoil (clay and sandy clay), lateritic clay, weathered bedrock (clay, sandy clay and clayey sand), fractured bedrock and fresh basement. A major discontinuity (fracture zone) was discovered along the S-N direction, while a weak zone was also discovered along E-W direction. The result of this research has shown that the causes of the cracks and distress on the walls within the site may have been influenced by the differential settlement resulting from the incompetent subsoil materials and the fractured bedrock on which the foundation of the building was laid.
\end{abstract}

Keywords: Foundation; Bedrock; Basement; Cracks; Subsurface Instability

\section{Introduction}

With the growing demand for site development and unpleasant experience of building failure, there is increasing number of necessary site investigations to reveal possible subsurface problems. Therefore, geophysical investigations are important in evaluating the physical properties of the subsurface in terms of its soil type, soil competence, soil corrosivity, depth to bedrock and lithologic sequence.

Site engineers, for reasons of cost and other considerations such as assumptions in structural design, sometimes fail to incorporate pre-construction investigations in their job schedule. A geophysical investigation is therefore necessary for the site to reveal possible future subsurface problems and proffer possible solutions before the erection of buildings.

\footnotetext{
${ }^{*}$ Corresponding author.
}

\section{Study Area}

The Study Area, shown in Figure 1, is geographically enclosed within latitude $7^{\circ} 36^{\prime} 95^{\prime \prime} \mathrm{N}$ to $7^{\circ} 37^{\prime} 55^{\prime \prime} \mathrm{N}$ and longitude $4^{\circ} 42^{\prime} 00^{\prime \prime} \mathrm{E}$ to $4^{\circ} 42^{\prime} 90^{\prime \prime} \mathrm{E}$, south-western, Ni geria. The climate is humid tropical type with a mean annual temperature of about $280^{\circ} \mathrm{C}$ and a mean annual rainfall of about $1600 \mathrm{~mm}$ [1]. Periods of high temperatures are recorded annually; the first period occurs in March-April and the second period in November-December, the coolest period is observed in the middle of the raining season [2]. Within the Southern Ilesa area, Nigeria; the schists are the most predominant rock type. They are medium-grained with abundant biotite and strongly foliated. Lenses of granular quartz are present [3]. The quartzite and quartz mica schist are probably younger than the gneisses and schists. Several belts of schists occur around the study area and range from massive, granular rocks to glassy schistose varieties. The 


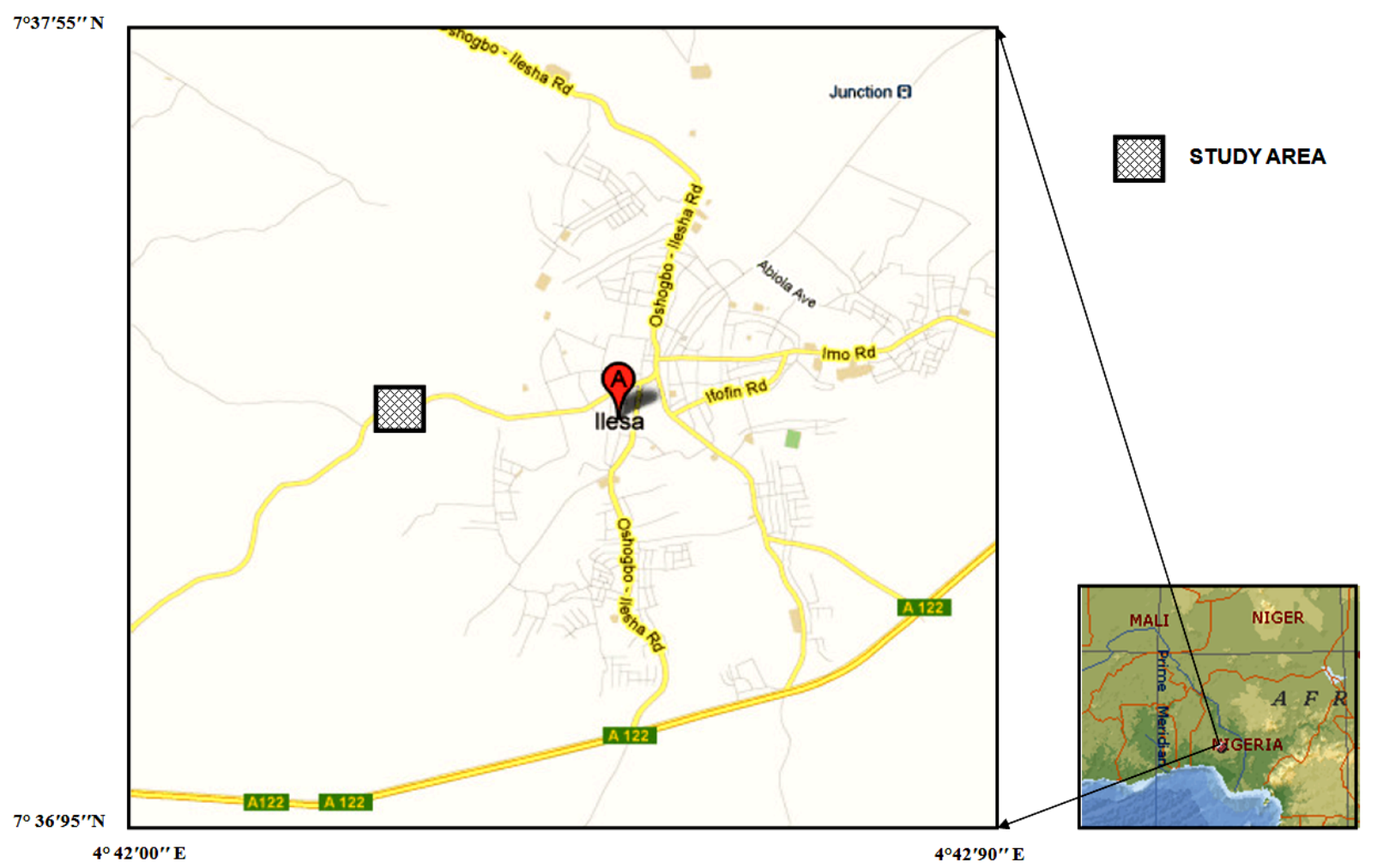

Figure 1. Sketch map of part of Ilesa showing the study area.

quarzite and quartz schists are resistant to weathering and therefore occur as distinct ridges with very steep slopes, but are highly fractured and jointed. Figure 2 is a geological map within the area $[4,5]$. The study area lies within the region of undifferentiated gneiss and magmatite as shown on the geological map.

Two traverses were established within the premises of the study area, which runs S-N and E-W respectively (Figure 3). Eight Vertical Electrical Soundings (VES) were occupied along the traverse that runs S-N, while seven Vertical Electrical Soundings (VES) were occupied along the traverse that runs E-W, the traverse lengths are $75 \mathrm{~m}$ and $100 \mathrm{~m}$ respectively. The locations of the VES were constrained by the manifestation of failure at the investigated site. A total of fifteen (15) Vertical Electrical Soundings (VES) with electrode separations $(\mathrm{AB} / 2)$ ranging from 1 to $65 \mathrm{~m}$ were conducted within the study area using DDR-2 resistivity meter. The location of each of the sounding station was recorded with the aid of ETRA F-10 (GPS) unit. The apparent resistivity measurement at each station was plotted on bi-logarithmic graph sheets. The curves were inspected visually to determine the number and nature of the layering. Partial curve matching was carried out for the quantitative interpretation of the curves. The results of the curve matching (layer resistivities and thicknesses) were fed into the computer as a starting model in an iterative forward modelling technique 1-D inversion pro- gram [6]. From the interpretation results (layer resistivities and thicknesses), two geoelectric sections along E-W and S-N directions and a histogram were produced. For the combined horizontal profiling as sounding technique, the same traverses where VES were carried out, were also used. The Dipole-Dipole array was used for the data acquisition. The inter-electrode spacing (a) of $5 \mathrm{~m}$ was adopted while inter-dipole separation factor (n) was varied from 1 - 5. The apparent resistivity values were calculated using $\pi n(n+1)(n+2) a$ as the geometric factor. 2-D inversion modeling of the Dipole-Dipole data was carried out using DIPROTM Software developed by the Korea Institute of Geoscience and Mineral Resources [7].

\section{Discussion of Results}

The results of this research work are presented as field curves, histogram, geoelectric sections, pseudosections and 2-D inversion models.

\subsection{Field Curves}

The interpretation of the sounding curves shows that seven curve types exist, viz: HA, KH, AA, HKH, QH, HK and KQ. The number of layers varies between 4 and 5 . $\mathrm{KH}$ curve type is the predominant curve type (Figure 4), constituting $46.66 \%$ of the total, HA and AA constitute $13.33 \%$, HKH, QH, HK and KQ constitute $6.67 \%$. Some of the typical curve types in the area are shown in 


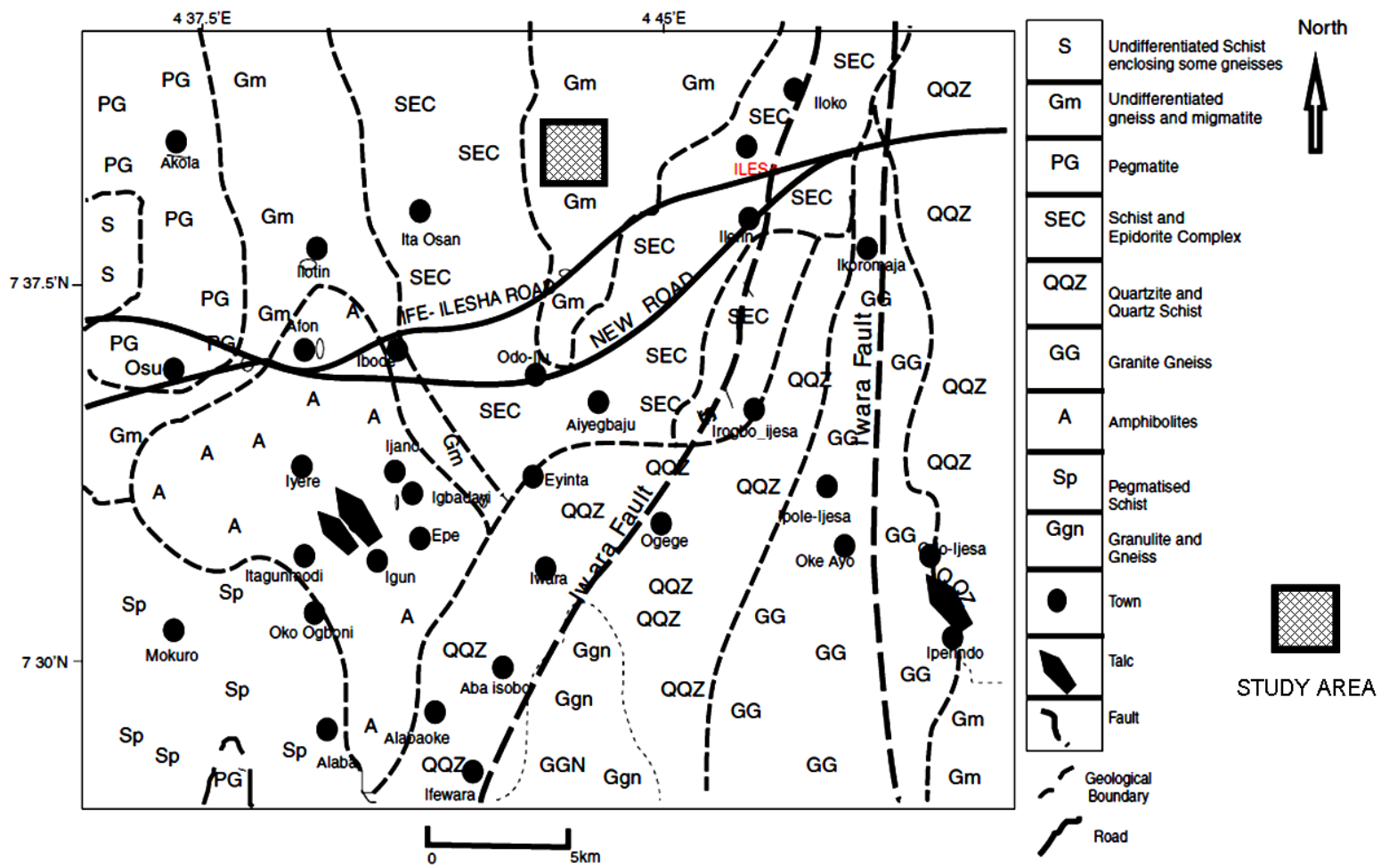

Figure 2. Geological map of southern part of Ilesa [4,5].
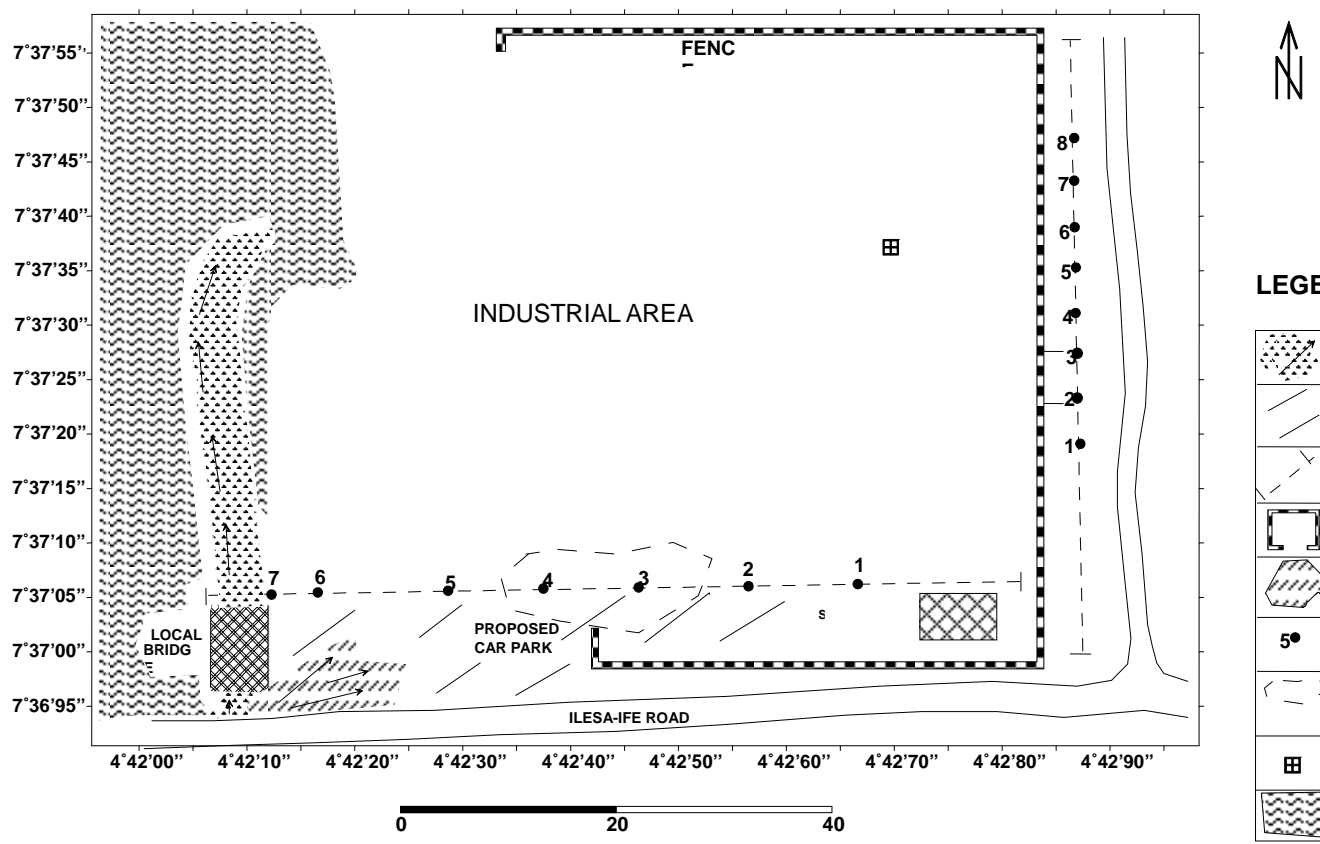

LEGEND

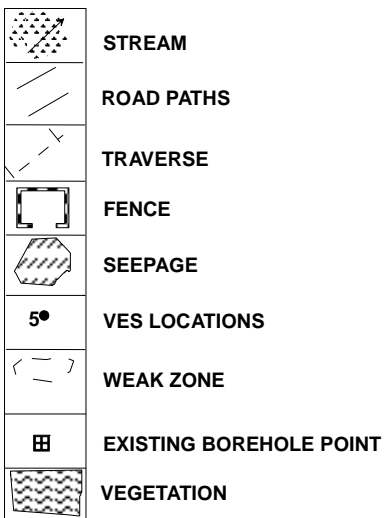

Figure 3. Geophysical data acquisition map of the site.

Figures 5(a)-(c). The implication of $\mathrm{KH}$ curve type as the predominant curve is that the underlying bedrock in the study area is characterised by confined fractures.

\subsection{Geoelectric Characteristics}

The geoelectric section along E-W direction (Figure 6) identified six geoelectric/geologic subsurface layers comprising the topsoil, lateritic clay, weathered bedrock, partially weathered bedrock, fractured bedrock and fresh basement. The compositions are clay/sandy clay/clayey sand topsoil (resistivity varies from 51 to $488 \mathrm{ohm}-\mathrm{m}$ and thickness ranges from $0.42-2.69 \mathrm{~m}$ ), lateritic clay 


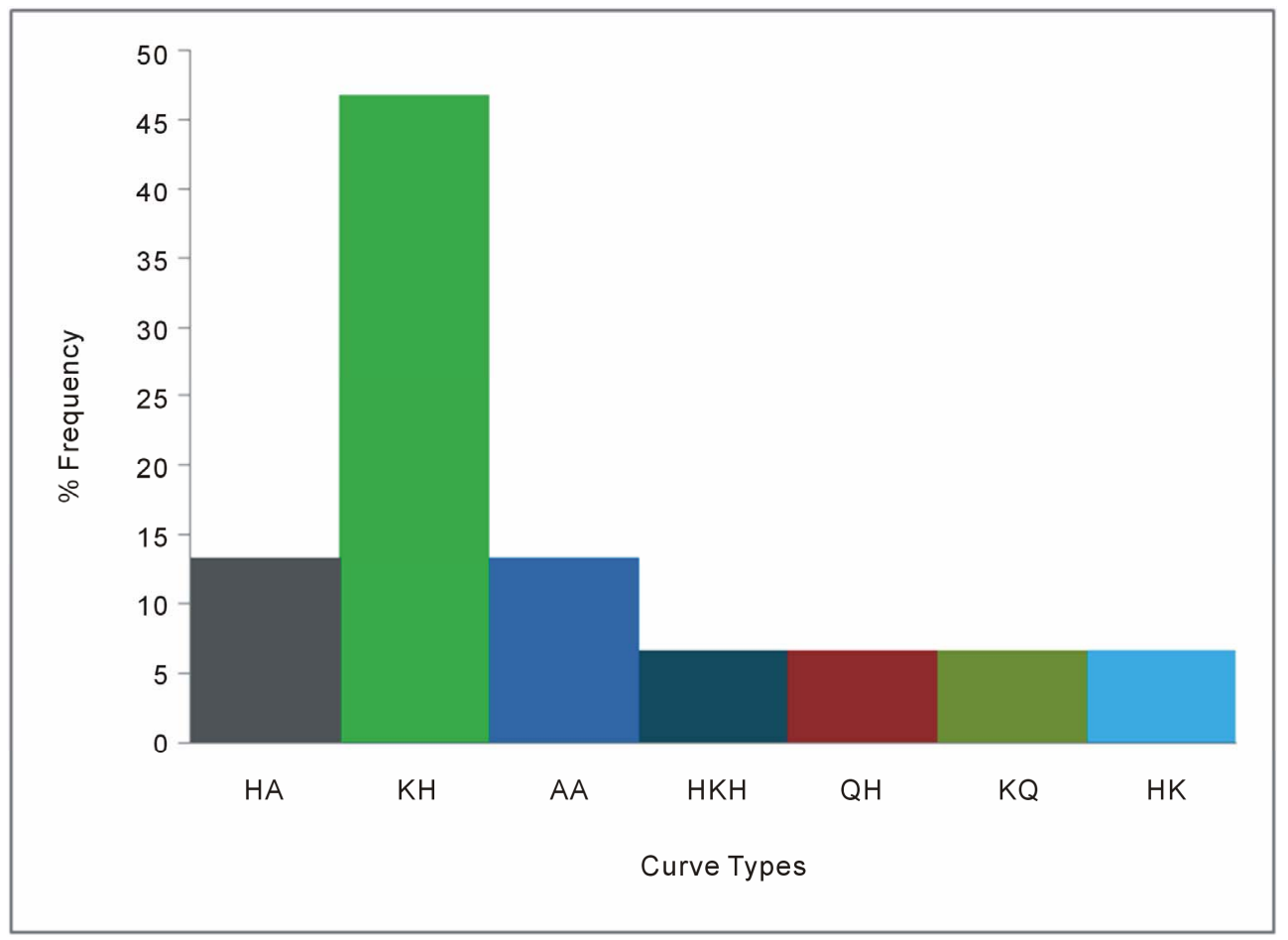

Figure 4. Histogram of the VES curve types of the study area.

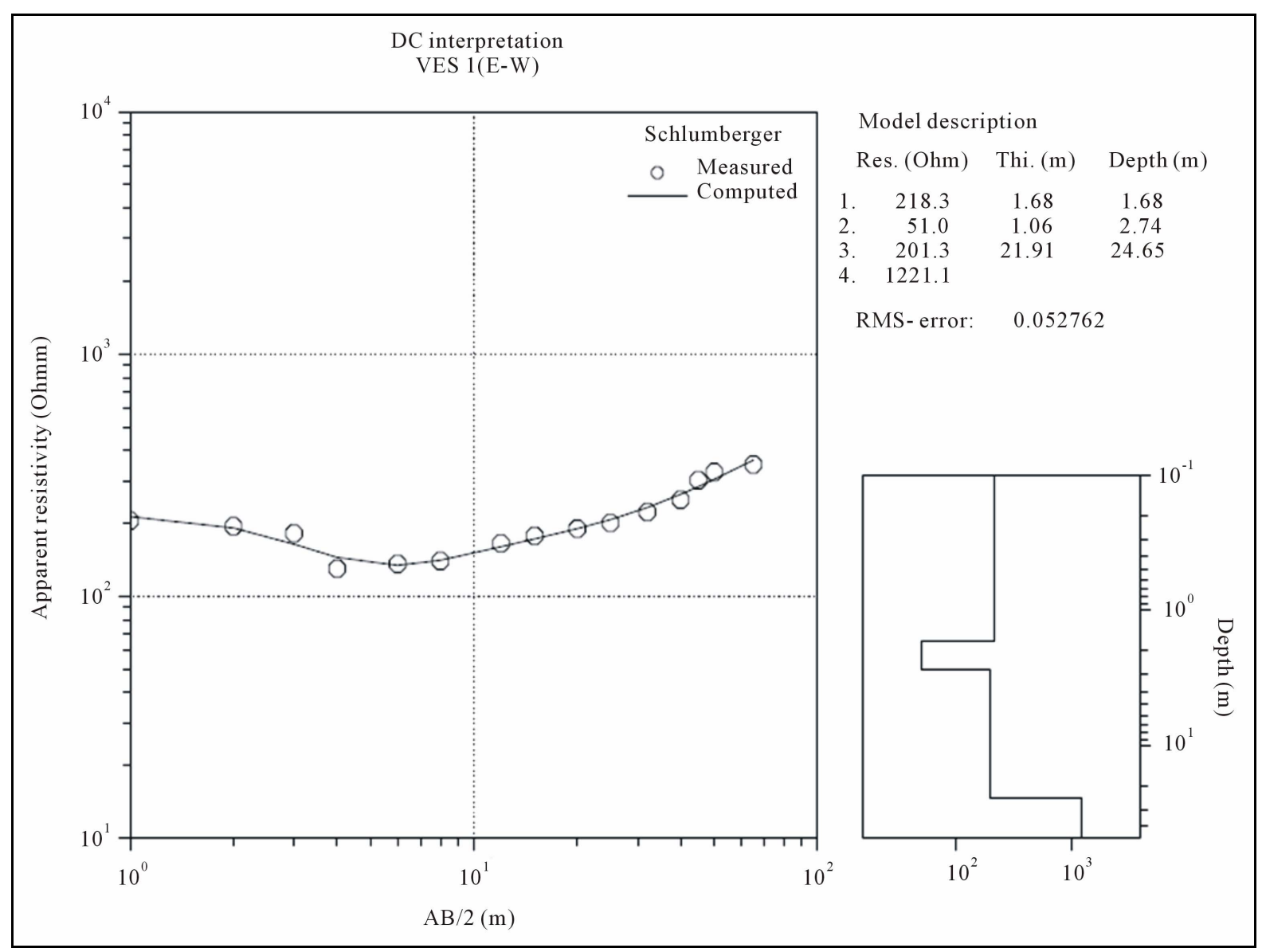

(a) 


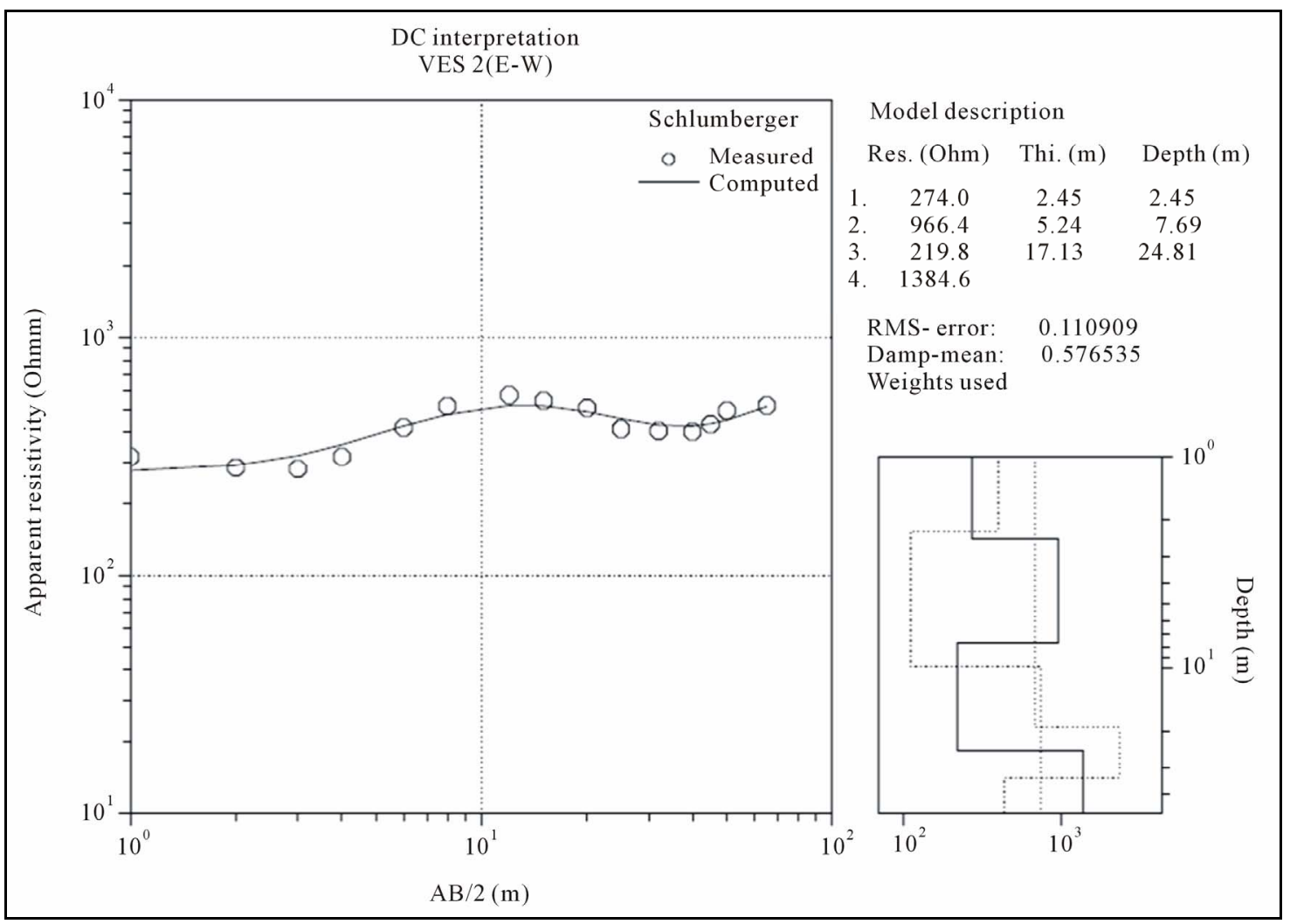

(b)

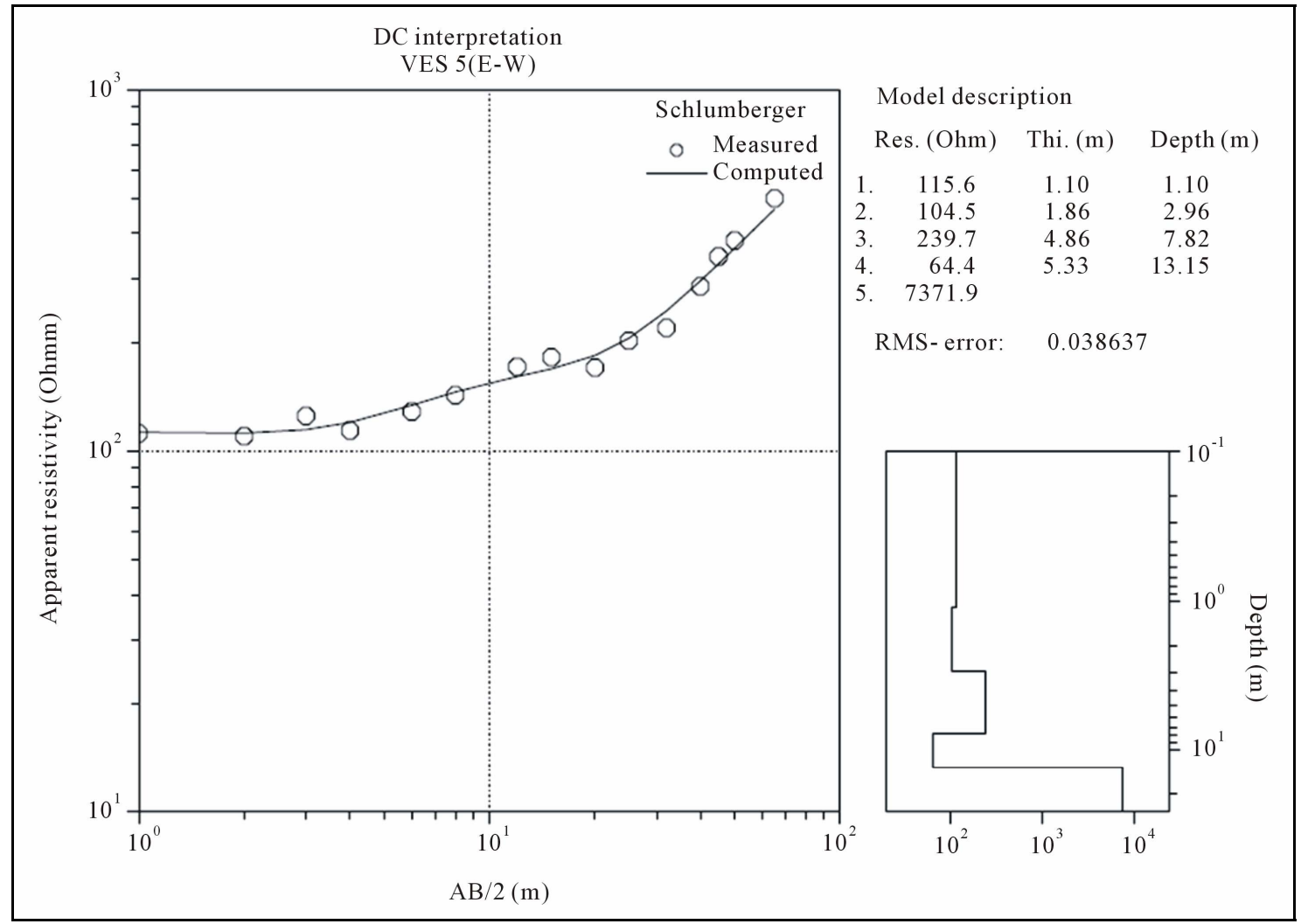

(c)

Figure 5. (a) Typical HA sounding curve; (b) Typical KH sounding curve; (c) Typical HKH sounding curve. 


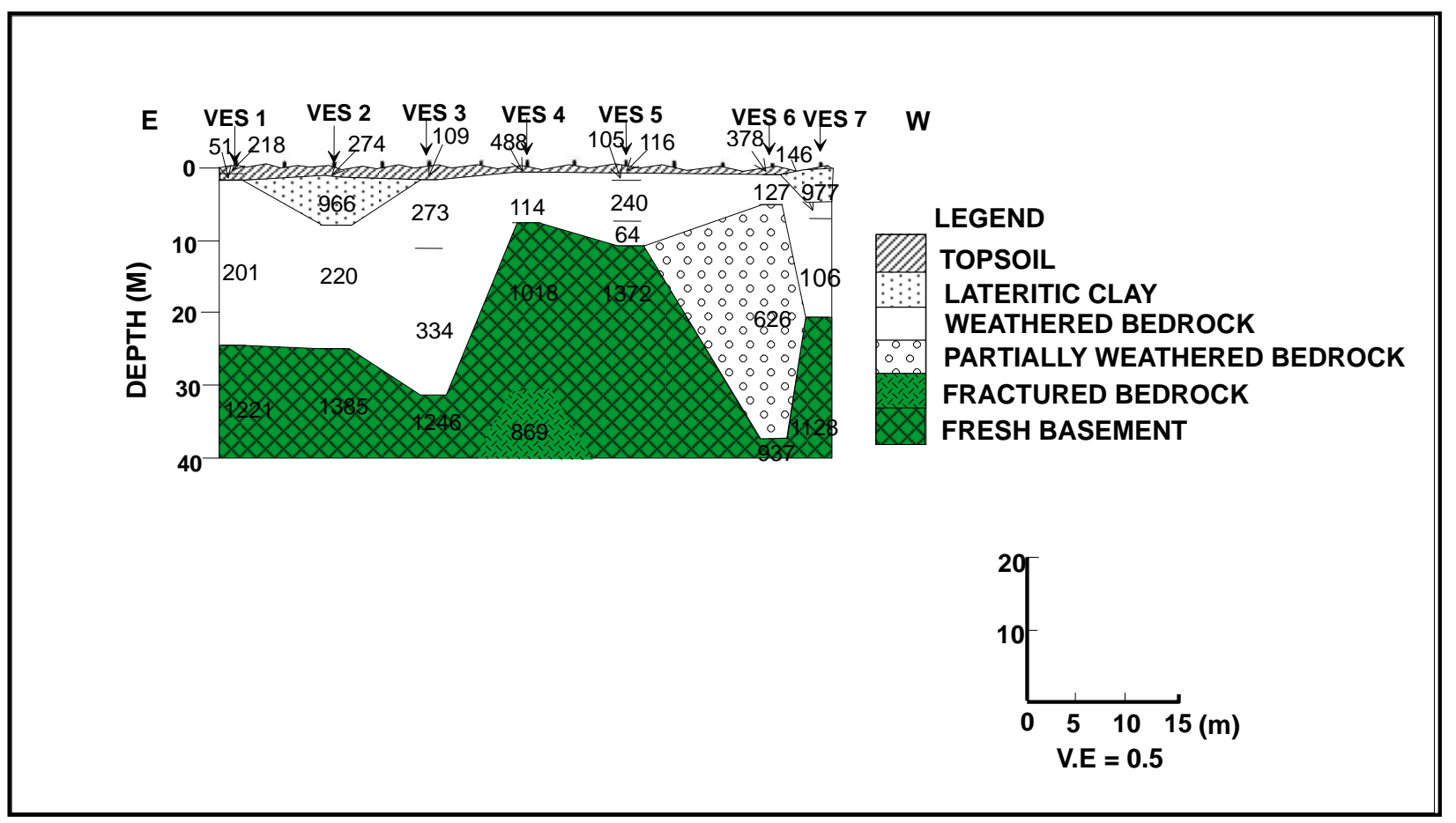

Figure 6. Geoelectric section along E-W direction.

(resistivity varies from 966 to $977 \mathrm{ohm}-\mathrm{m}$ and thickness ranges from 4.10 - $5.24 \mathrm{~m}$ ) localized at VES 2 and VES 7, clay/sandy clay/clayey sand weathered bedrock (resistivity varies from 64 to $334 \mathrm{ohm}-\mathrm{m}$ and thickness ranges from $6.77-29.08 \mathrm{~m}$ ), partially weathered bedrock (resistivity of $626 \mathrm{ohm}-\mathrm{m}$ and thickness of $30.62 \mathrm{~m}$ ) beneath VES 6, fractured bedrock (resistivity of $869 \mathrm{ohm}-\mathrm{m}$ ) beneath VES 4 which is a confined fracture and fresh basement (resistivity varies from $937 \mathrm{ohm}-\mathrm{m}$ to $1385 \mathrm{ohm}-\mathrm{m}$ ). The depth to rock head ranges from $7.19 \mathrm{~m}$ to $36.17 \mathrm{~m}$. The overburden is generally thick but thinnest at VES 4 $(7.19 \mathrm{~m})$ and thickest at VES $6(36.17 \mathrm{~m})$ at the western flank, both along East-West direction. The basement relief is undulating; basement depression is noticed at VES $3(\mathrm{E}-\mathrm{W})$ and VES $6(\mathrm{E}-\mathrm{W})$.

The geoelectric section along S-N direction (Figure 7) identified five geoelectric/geologic subsurface layers comprising the topsoil, lateritic clay, weathered bedrock, partially weathered bedrock and fresh basement. The compositions are sandy clay/clayey sand topsoil (resistivity varies from 120 to $246 \mathrm{ohm}-\mathrm{m}$ and thickness ranges from $0.75-3.52 \mathrm{~m}$ ); lateritic clay (resistivity varies from 664 ohm-m to 3205 ohm-m and thickness ranges from 2.93 - $16.16 \mathrm{~m}$ ); weathered bedrock (resistivity varies from $91 \mathrm{ohm}-\mathrm{m}$ to $389 \mathrm{ohm}-\mathrm{m}$ ), partially weathered bedrock (resistivity of $423 \mathrm{ohm}-\mathrm{m}$ ) localized at VES 5 showing that it extends beyond the depth of study $(60 \mathrm{~m})$ and fresh basement (resistivity of 3937 ohm-m).

The results of the field curves and geoelectric sections generally indicate five main geoelectric layers; namely the topsoil (resistivity varies from 51 to $488 \mathrm{ohm}-\mathrm{m}$ and thickness ranges from $0.42-3.52 \mathrm{~m}$ ), lateritic clay (664 to $3205 \mathrm{ohm}-\mathrm{m}$ and thickness ranges from $2.93-16.16$ $\mathrm{m}$ ), weathered bedrock (resistivity varies from $64 \mathrm{ohm}-\mathrm{m}$ to 393 ohm-m), fractured bedrock (resistivity of 869 ohm-m) and fresh basement (resistivity varies from 937 ohm-m to $3937 \mathrm{ohm}-\mathrm{m}$ ). The topsoil generally varies in composition from clay to sandy clay, but predominantly composed of sandy clay. The fracture zones are generally confined and extend beyond the depth of study.

\subsection{Combined Horizontal Profiling (HP) and Vertical Electrical Sounding (VES)}

The Dipole-dipole psudosection and the 2D resistivity structure along E-W direction are shown in Figure 8. The 2D resistivity structure revealed four geoelectric layers marked by A, B, C and E separated by geologic boundaries; namely topsoil marked by A (generally green colour except at few points with yellow and red colour); weathered bedrock marked by B (generally green with few yellow colour); lateritic clay marked by $\mathrm{C}$ (yellow and red colour) and fresh basement marked $E$ (red and purple colour). The topsoil is generally thin and subsume into the weathered bedrock in many places due to its characterized by lateritic clay between stations 15 and 16 and sandy clay between stations 13 and 15, but generally composed of clay at the other stations. The weathered bedrock (B) is characterized by two potentially saturated 


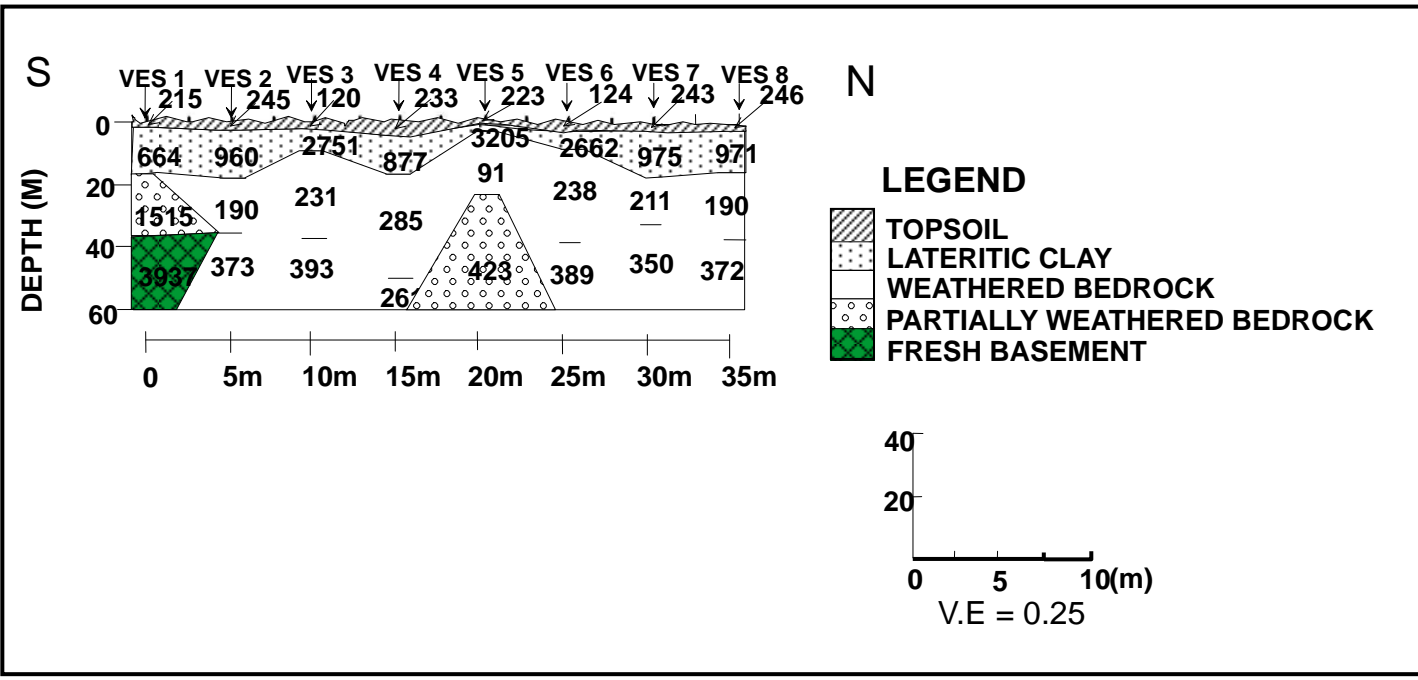

Figure 7. Geoelectric section along S-N direction.

$E$

(E-W) TRAVERSE (Field Data Pseudosection)

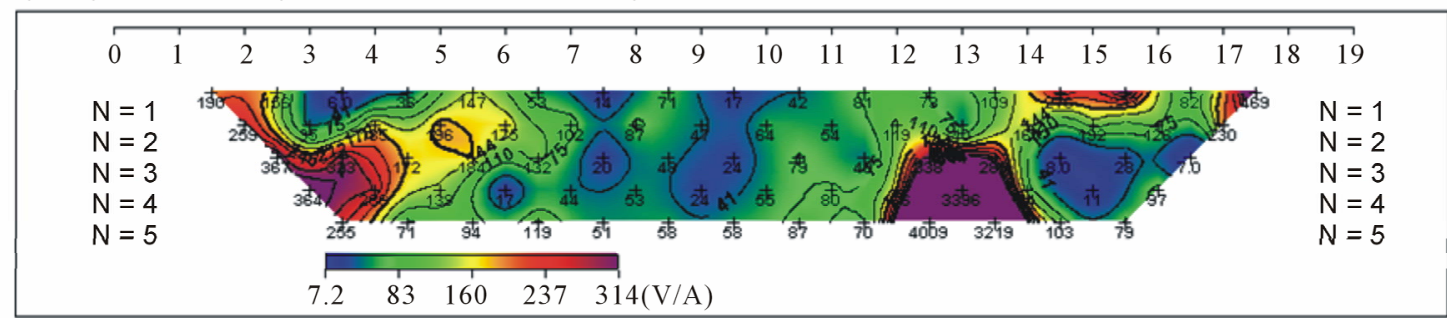

(E-W) TRAVERSE (Theoretical Data Pseudosection)

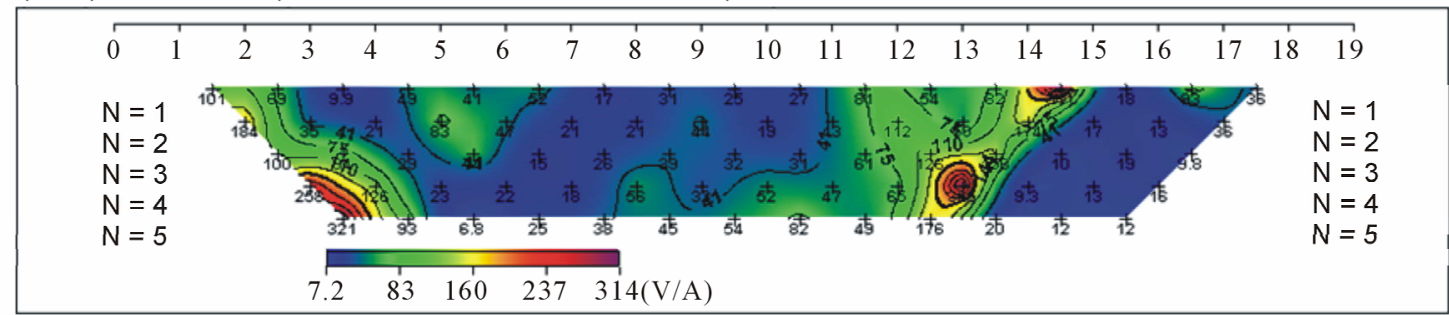

(E-W) TRAVERSE (2-D Resistivity Structure)

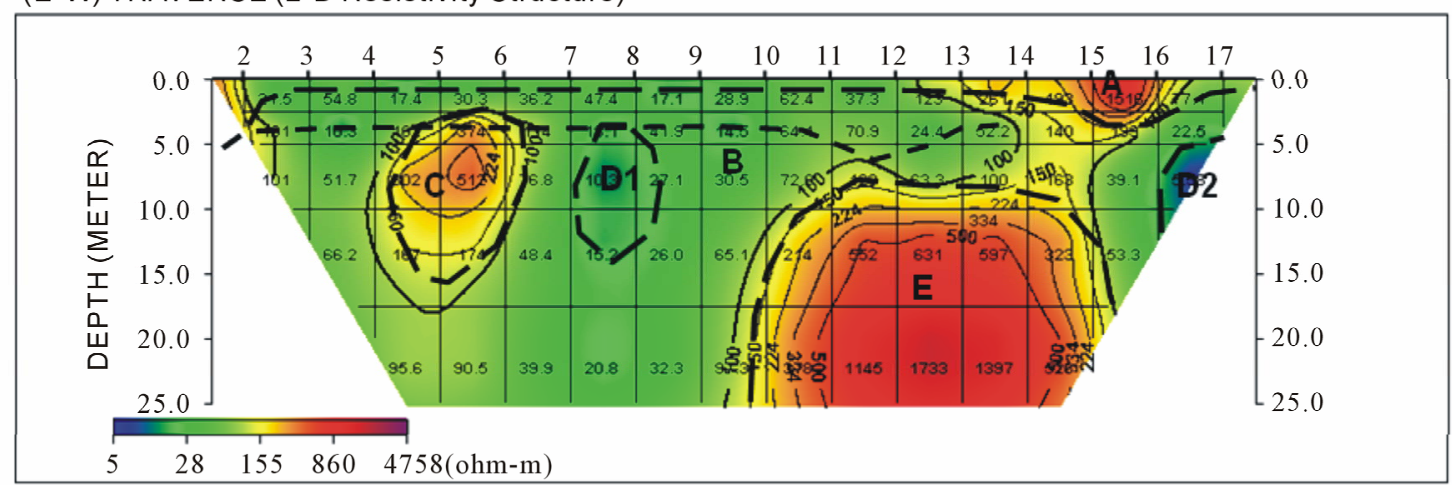

Figure 8. 2-D Modeling of dipole-dipole along E-W direction.

zones with very low resistivity values marked D1 and D2 respectively which could be the diagnostic effect of wet clay. Between stations 4 and 6 at depth of $2.5 \mathrm{~m}$, the presence of lateritic clay is noticed in the weathered layer 
by an oval shaped unit with a higher resistivity value than its surroundings. This could be as a result of the deposition that was left after weathering. The weathered bedrock (B) is characterized by sandy clay due to its low resistivity values but with higher portion of clay between stations 6 and 10 which falls within the weak segment of the investigated premises. The depth to bedrock is thicker between stations 2 and 10, but decreases towards the western flank (between stations 10 to 15 ). Between these stations, the thickness of the overburden has decreased but with higher resistivity thus, signifying a lower portion of clay when compared to the eastern flank, the overburden is directly underlain by competent bedrock (E) which extends beyond the depth of study $(25 \mathrm{~m})$. The Dipole-dipole pseudosection and the 2D resistivity structure along S-N are presented in Figure 9.
The 2D resistivity structure revealed four geoelectric/geologic layers marked A, B, C and D which are separated by geologic boundaries namely; topsoil marked A (green and yellow colour); lateritic clay marked by B (red and purple colour); Weathered bedrock marked C (green colour) and fractured basement (blue colour). The topsoil is generally thin and composed of clay and sandy clay, but subsumes into the underlying lateritic clay in many places. A major discontinuity flanked on both sides by regions of higher resistivity was noticed between stations 6 and 11, this discontinuity which extends beyond the depth of study $(25 \mathrm{~m})$ is in form of an oval shaped unit which has concentric inner (D) and outer (C) regions, gradual decrease in resistivity values occurs from the outer region $(C)$ to the inner region (D). The fracture zone (D) (inner region of the oval shaped unit) is the

$S$

(S-N) TRAVERSE (Field Data Pseudosection)

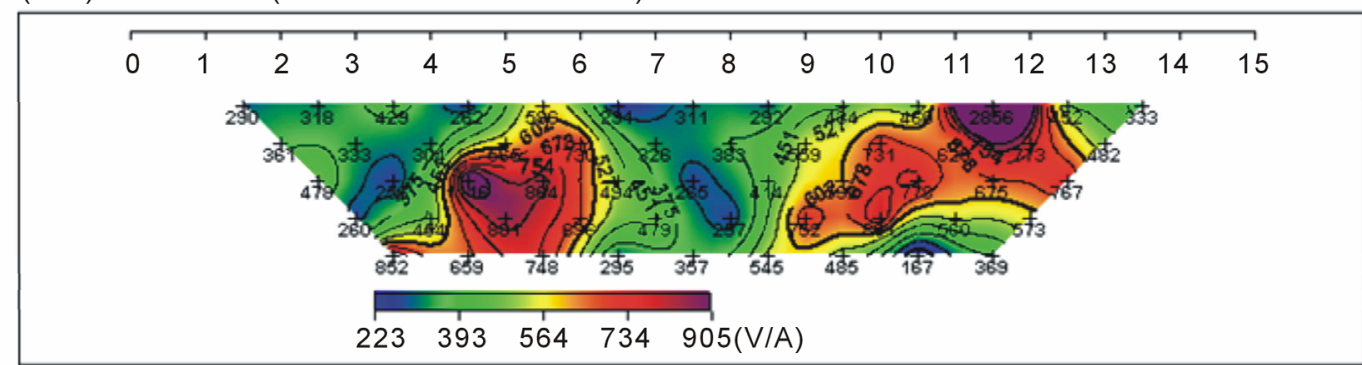

(S-N) TRAVERSE (Theoretical Data Pseudosection)

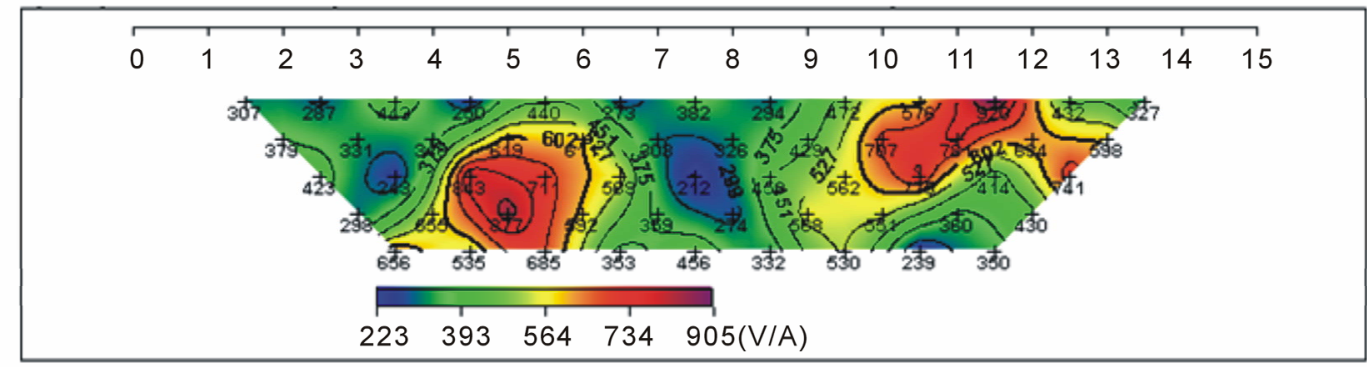

(S-N) TRAVERSE (2-D Resistivity Structure)

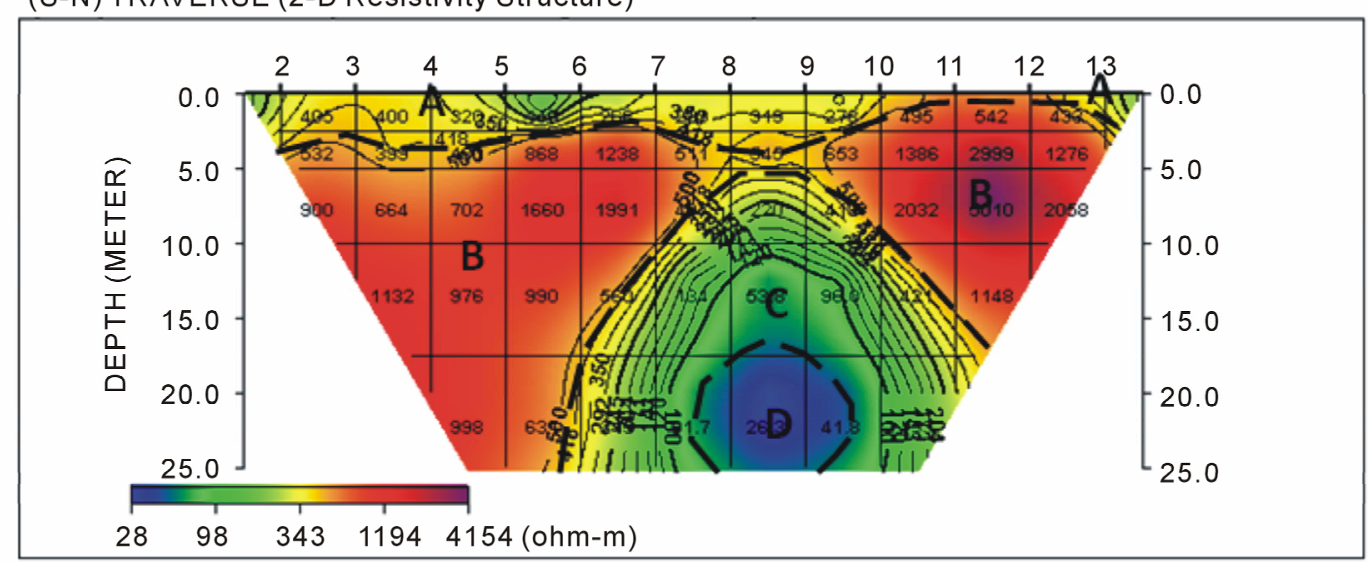

Figure 9. 2-D Modeling of dipole-dipole along S-N direction. 
zone of lowest resistivity value.

\subsection{Synthesis of Results}

Along E-W traverse direction, the geoelectric section and the $2 \mathrm{D}$ resistivity structure shows that the topsoil is generally thin except for the significant thick lateritic clay at VES 7 which shows similar characteristics between stations 15 and 16 on the 2D resistivity structure. The topsoil also varies in composition from clay to sandy clay with small portion of clayey sand. The lateritic clay beneath VES 2 (Figure 10) at depth of $2.45 \mathrm{~m}$ is shown between stations 4 and 6 at the same depth in form of an oval shaped unit with higher resistivity value. The weathered bedrock varies in composition from clay to sandy clay to clayey sand, but predominantly composed of sandy clay. The saturated zone D1 at depth 2.69 m correlates with a low resistivity zone between VES 2 and VES 4 (Figure 10). The basement depression at VES 6 corresponds with the same basement depression between stations 14 and 15, the confined fracture beneath VES 4 corresponds with the basement depression between stations 9 and 10. The geoelectric section shows that starting from VES 1 to VES 4, the depth to bedrock is beyond $25 \mathrm{~m}$, this correlates with the $2 \mathrm{D}$ resistivity structure between stations 3 and 10 which shows that the bedrock is deeper, i.e. beyond the depth of study $(25 \mathrm{~m})$.

Along S-N direction, both the geoelectric section and the $2 \mathrm{D}$ resistivity structure reveals that the topsoil is gen- erally thin (Figure 11). The lateritic clay underlying the topsoil on the geoelectric section correlates with the lateritic clay (B) on the 2D resistivity structure at the same depth. The discontinuity noticed between stations 6 and 11 which show gradual decrease in resistivity values from depth $2.7 \mathrm{~m}$ correlates with the gradual decrease in resistivity values between VES 2 and VES 7. The outer region $(\mathrm{C})$ of the oval shaped unit on the $2 \mathrm{D}$ resistivity structure correlates with the weathered bedrock on the geoelectric section (Figure 11) while inner region (D) correlates with the partially weathered bedrock on the geoelectric section (which extends beyond the depth of study $(25 \mathrm{~m})$ for the 2D resistivity structure) (Figure 11). The resistivity increases with depth from the zone of lowest resistivity (D), the partially weathered bedrock has a higher resistivity and also at a higher depth, therefore the fracture zone (D) is underlain by partially weathered bedrock.

\subsection{Subsoil Evaluation of the Study Area}

From the results of the $2 \mathrm{D}$ resistivity structure and the geoelectric sections, the overburden is composed of clay, sandy clay, clayey sand and lateritic clay, but predominantly composed of sandy clay which has higher clay to sand ratio. Due to the incompetent nature of clayey soils, the overburden will not be able to host heavy buildings without excavating and refilling with competent materials such as sand/gravel and laterite. The underlying

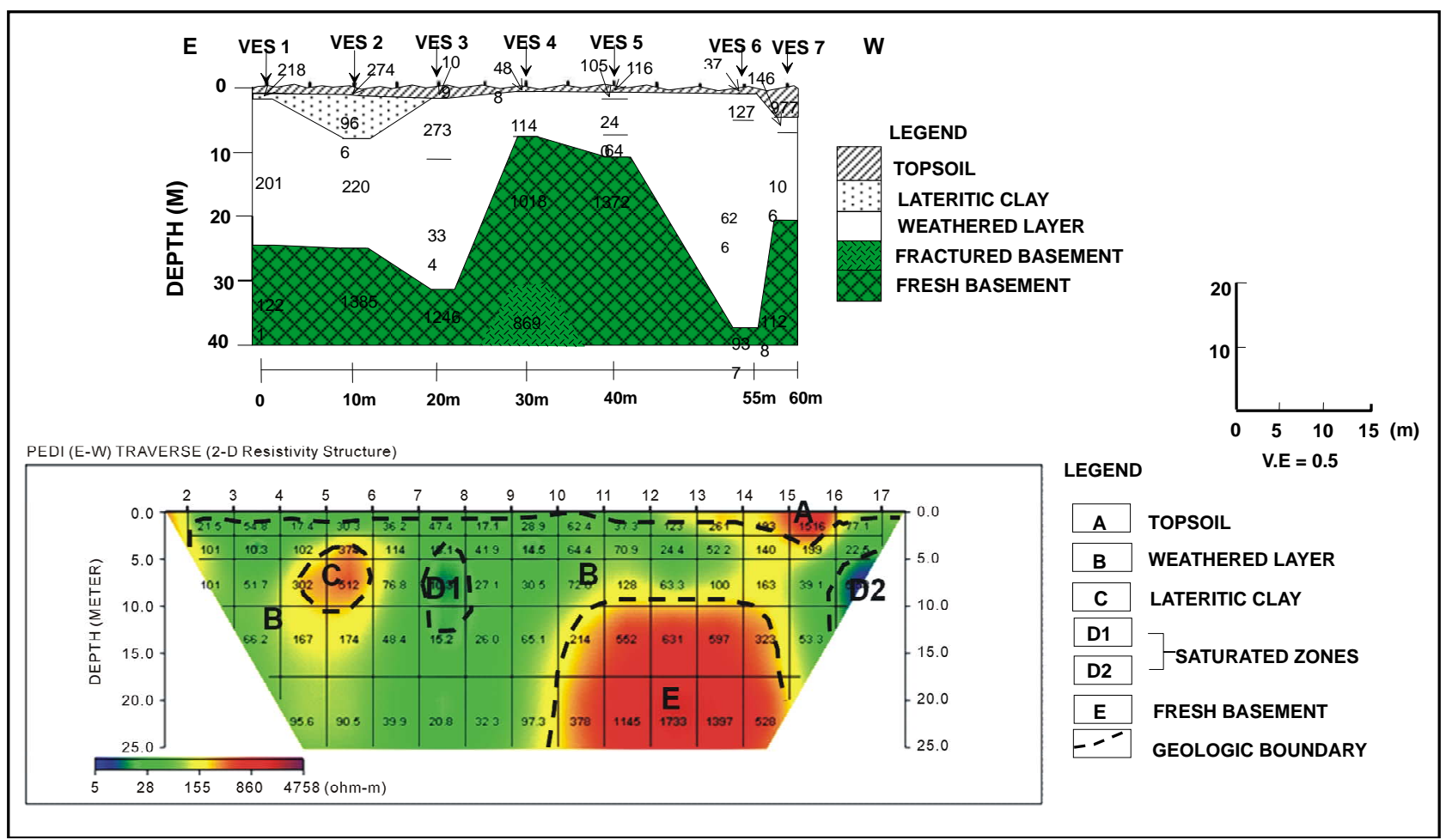

Figure 10. Geoelectric section and 2-D resistivity structure along E-W direction. 


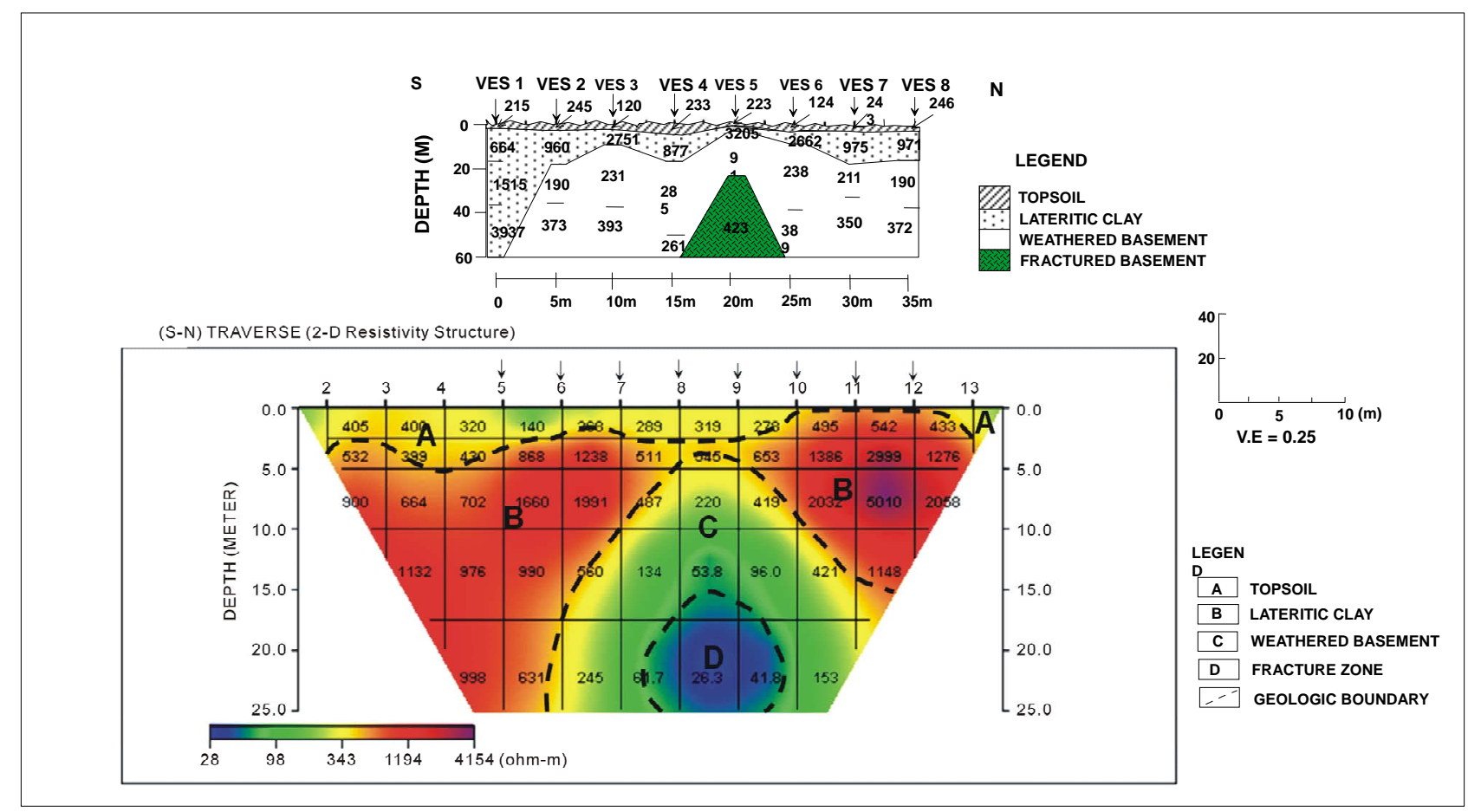

Figure 11. Geoelectric section and 2-D resistivity structure along S-N direction.

basement is fractured in most places i.e., these fracture zones are confined within the basement. Confined fractures which can act as weak zones within the basement can manifest as differential settlement of the hosted building and shows as cracks on the erected walls. Along the South-North, the topsoil is predominantly composed of sandy clay which has high clay to sand ratio, which manifests as cracks on the surface of the ground. Along the East-West direction, it was noticed that the western flank has higher resistivity values than the eastern flank, this can result in uneven stress distribution i.e., one side has a stronger support than the other. A major weak zone was noticed between stations 6 and 11 on 2D resistivity structure. It was observed that a nearby stream that flows beneath a local bridge gradually seeps through the sandy clay compartments (which has higher permeability than clay) on the western flank (on top of the competent bedrock marked E) towards the eastern flank (lowest part of the competent bedrock marked E) to the weak zone observed between stations 6 and 11. This weak zone is composed mainly of clay which is porous but not permeable resulting in the saturated zone (D1) caused by trapped water in the clay compartments.

\section{Conclusion}

A geophysical investigation involving the electrical resistivity method was carried out at a study location in south-western Nigeria. The electrical resistivity method utilized the Vertical Electrical Sounding (VES) and Elec- trical Imaging techniques. Five main geoelectric sequences were delineated within the study area. These include the topsoil, lateritic clay, weathered bedrock, fractured bedrock and fresh basement. The topsoil and weathered layer are composed of clay, sandy clay and clayey sand formation. A major discontinuity (confined fracture zone) was identified by the electrical imaging on bedrock along the S-N direction. This would have been the reason for differential settlement, since it was confirmed that the foundation of the structure was placed on this weak bedrock. Moreover, the topsoil along the S-N direction is predominantly composed of sandy clay which has high clay to sand ratio, this manifest as cracks on the surface of the ground. A major weak zone which has saturated zone was also discovered along the E-W direction. The result of this research has shown that the causes of the cracks and distress on the walls within the site may have been influenced by the differential settlement resulting from the incompetent subsoil materials and the fractured bedrock on which the foundation of the building was built. In conclusion, the importance of pregeophysical investigation before the erection of buildings cannot be overemphasized, since this will help in designing of such proposed buildings that will be able to withstand subsurface instability with time.

\section{REFERENCES}

[1] O. O. Orimoogunje, R. O. Oyinloye and M. Soumah, "Geospatial Mapping of Wetlands Potential in Ilesa, 
Southwestern Nigeria," TS 4B-SDI in Municipality and Natural Resources Management, FIG Working Week, 2009.

[2] J. S. Kayode, P. K. Nyabese and A. O. Adelusi, "Ground Magnetic Study of Ilesa East, Southwestern Nigeria," African Journal of Environmental Science and Technology, Vol. 4, No. 3, pp. 122-131.

[3] E. A. Ariyibi, S. L. Folami, B. D. Ako, T. R. Ajayi and A. O. Adelusi, "Application of Principal Component Analysis on Geochemical Data: A Case Study in the Basement Complex of Southern Ilesa Area, Nigeria," Arabian Journal of Geosciences, Vol. 4, No. 1-2, 2010, pp. 239-247. http://dx.doi.org/10.1007/s12517-010-0175-5
[4] A. O. Adelusi, "Multi-Method Geophysical Investigation for Groundwater Study in Southeastern Part of Ilesa Area, Osun State Southewestern Nigeria," Ph.D. Thesis, Federal University of Technology, Akure, 2005.

[5] A. B. Adebayo, "Physico-Chemical Characteristics of Groundwater in Two Mining Areas of Contrasting Lithologies in the Ife-Ilesa Schist Belt," B.Sc. Thesis, Obafemi Awolowo University, Ile-Ife, 2006.

[6] M. Pirttijärvi, "DCINV: 1-D Interpretation of Electrical (DC) Soundings Software," Oulu, 2005.

[7] KIGAM, "DIPRO Version 4.01, Processing and Interpretation Software for Electrical Resistivity Data," KIGAM, Daejeon, 2001. 